\title{
Seasonality of Fruit-Feeding Butterflies (Lepidoptera, Nymphalidae) in a Brazilian Semiarid Area
}

\author{
Carlos Eduardo Beserra Nobre, ${ }^{1}$ Luciana Iannuzzi, ${ }^{1}$ and Clemens Schlindwein ${ }^{2}$ \\ ${ }^{1}$ Departamento de Zoologia, Universidade Federal de Pernambuco, Cidade Universitária, Avenida Prof. Morais Rego, S/N, \\ 50670-901 Recife, PE, Brazil \\ ${ }^{2}$ Departamento de Botânica, Universidade Federal de Minas Gerais, Avenida Antônio Carlos, 6627, Pampulha, \\ 31270-901 Belo Horizonte, MG, Brazil
}

Correspondence should be addressed to Carlos Eduardo Beserra Nobre, cebnobre@gmail.com

Received 14 April 2012; Accepted 29 May 2012

Academic Editors: M. Kohda, K. Lunau, and B. A. Young

Copyright () 2012 Carlos Eduardo Beserra Nobre et al. This is an open access article distributed under the Creative Commons Attribution License, which permits unrestricted use, distribution, and reproduction in any medium, provided the original work is properly cited.

\begin{abstract}
A survey of 6,000 trap/hours using fruit-bait traps was conducted, in order to characterize the community of fruit-feeding butterflies and their seasonal variation in a semiarid area of NE Brazil, which exhibits a highly seasonal rainfall regime. The community was composed of 15 species, the four most abundant comprising more than $80 \%$ of the total individuals. In the first sampling month, $80 \%$ of the species had already been recorded. A strong positive correlation was found between butterfly abundance and precipitation of the sampled year. The highly seasonal pattern of the studied community may be related to the availability of both larvae and adult food resources. The endemic Fountainea halice moretta presented the highest positive correlations with other butterfly species and with total butterfly abundance and illustrates well the seasonal variation of the whole community. Hamadryas februa was the only species trapped in all sampling months, probably due to the ability of adults to aestivate during the dryer months. The open and more disturbed sample area showed higher abundance of butterflies in the rainy season and lower abundance in the dry season. Both abundance and richness were affected by season in a manner that the rainy period had significantly more individuals and species.
\end{abstract}

\section{Introduction}

Butterflies attracted to fruitbaits have been extensively studied in the past two decades to evaluate the conservation state of natural areas, effects of land management and fragmented habitat, monitoring of populations and to assess ecological parameters [1-7]. In the neotropics, the frugivorous trophic guild constitutes a considerable portion of the family Nymphalidae and is formed by Charaxinae, Biblidinae, Morphinae, Satyrinae, and Nymphalinae: Coeini. Butterflies in these groups feed mainly on the juices of fermented fruits but also on dung, plant exudates, and carrion [8].

In Brazil, studies of this guild have been conducted in rainforests [7, 9-11] and Cerrado [12, 13]. In the dry northeastern part of the country, the Caatinga, the only lepidopteran group methodically studied, is the family Sphingidae $[14,15]$ stated as highly seasonal in this ecosystem.
Regarding butterflies, a single checklist is available for this area [16], but there are no studies concerning its fruit-feeding butterfly fauna.

The Caatinga covers an area of approximately $800,000 \mathrm{~km}^{2}$, which is about $10 \%$ of the Brazilian territory [17]. It is mainly a thorn-shrub succulent savanna with several physiognomies, depending on local rain regime and soil constitution. It is characterized by a semiarid climate and highly seasonal rainfall regimes $[18,19]$. The region is still poorly studied and highly susceptible to disturbance, due to a growing and misguided natural resources use [20,21].

In the tropics, periods of drought and intense rainfall are strong regulators of the seasonal flowering cycles [22], leading to a direct response of the insect communities that rely on leaves, flowers, and fruits as feeding resources. Janzen [23] suggests that all ecological aspects of Costa Rican insects have a seasonal influence. In most of the seasonal areas of 


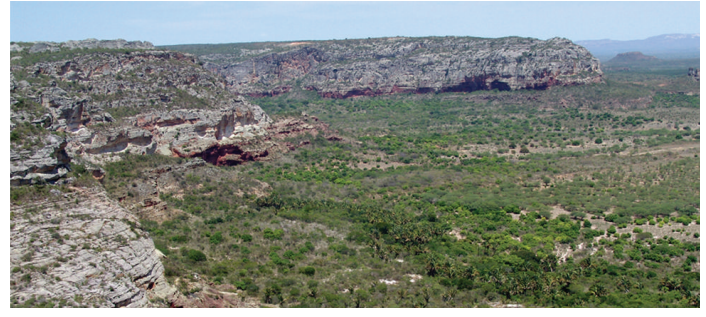

(a)

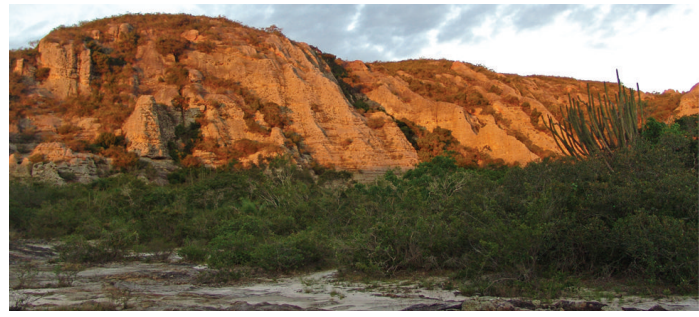

(b)

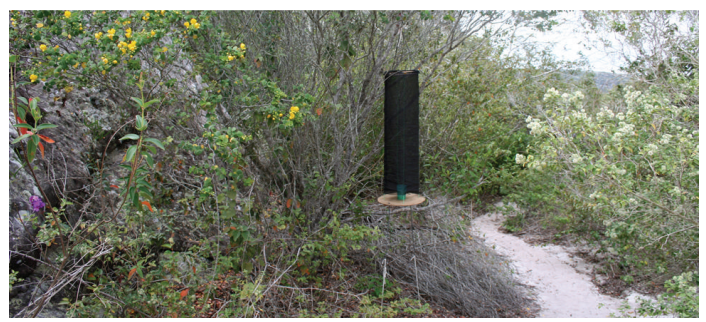

(c)

Figure 1: Aspects of the Catimbau National Park, Pernambuco, Brazil. (a) Arenitic rocky formation and vegetation aspect during the middry season, (b) shrublike vegetation on rocky substrate, and (c) bait-trap set over sandy soil.

this country, butterflies show strong abundance fluctuations throughout the year [24]. In Brazilian Cerrado stricto sensu, which also exhibits strong seasonality, butterflies oviposit mainly during the rainy season [25], but Pinheiro et al. [26], on the other hand, detected no correlations between seasonality and abundance of Lepidoptera.

The aim of this study was to verify the seasonal influences on the abundance, richness, and composition of fruit-feeding butterflies from an area of the Brazilian semiarid, during the course of one year. We tested the hypothesis that all previously mentioned parameters are strongly correlated to precipitation, being higher during the rainy season.

\section{Materials and Methods}

2.1. Study Area. The Catimbau National Park $\left(8^{\circ} 24^{\prime} 00^{\prime \prime}-\right.$ $8^{\circ} 36^{\prime} 35^{\prime \prime} \mathrm{S}$. $\left.37^{\circ} 09^{\prime} 30^{\prime \prime}-37^{\circ} 14^{\prime} 40^{\prime \prime} \mathrm{W}\right)$ covers an area of 62,554 ha. in the municipalities of Buíque, Tupanatinga and Ibimirim, state of Pernambuco, Northeastern Brazil [27]. The region exhibits a tropical semi-arid climate, with annual average temperatures of $23^{\circ} \mathrm{C}$ and average precipitation varying from 700 to $1,100 \mathrm{~mm}$ per year, concentrated between March and July [28].

The topography is irregular, with plain areas and steep arenitic rocky formations, and altitudes ranging from 600 to 1,000 meters (Figure 1). The local vegetation is considered of extreme biological importance [29] and is composed of endemic species of the Caatinga and also elements of Cerrado and Atlantic Rainforest [27, 30].

2.2. Sampling Procedures. To sample the butterflies, five sites with different physiognomies were established: (I) a narrow trail occasionally used by people and cattle, with small trees and shrubs and a thin layer of litter over sandy soil; (II) an area of natural gaps between small trees and shrubs on a predominantly rocky substrate; (III) similar to site (I), but with less human usage; (IV) a trail following the base of a steep arenitic rocky slope, about $80 \mathrm{~m}$ high; (V) a disturbed area, predominantly open, with sparse trees and adjacent pasture/corn plantation, depending on the season.

At all sites, most trees were up to 5-7 $\mathrm{m}$ high. One Sample unit (SU), consisting of five bait traps each, was placed in each site, avoiding very sunny areas. The traps were adapted from the model proposed by DeVries [8], in order to prevent the escape and desiccation of the butterflies and evaporation of the baits in this hot and dry region. Thus, a plywood sheet was inserted on the superior part of the cylinder to avoid direct sunlight, and $15 \mathrm{~cm}$ high cups were used for the baits.

The used bait was a mixture of mashed bananas and sugar cane juice, fermented for 48 hours. Traps were placed at a minimum distance of $20 \mathrm{~m}$ among each other, 1.8 to $2.2 \mathrm{~m}$ above the ground, depending on the availability of partly shaded spots and tree branches strong enough to maintain them stable. Therefore, in a few cases the distance between traps reached $45 \mathrm{~m}$. The traps were kept in the sites for two days per month, from September 2005 to August 2006. They were placed on sunny days between 06:00 and 08:00 and checked on the following morning, when bait was also replaced, totaling 10 trap/hours per day.

The number of individuals of each species was recorded in each site. All individuals were marked by removing scales on the apices of the fore wings, to avoid recounting.

The nomenclature of the butterflies followed Lamas et al. [31].

2.3. Statistical Analyses. Simple linear correlations were made between climatic variables and the monthly species richness and abundances, using the software Statistica 6.0 [32]. To determine which species best represented seasonal fluctuations of the local butterfly community, Pearson's 
TABLe 1: Fruit-feeding butterflies sampled in the Catimbau National Park, from September/2005 to August/2006.

\begin{tabular}{|c|c|c|c|c|c|c|c|c|c|c|c|c|c|c|c|c|}
\hline \multirow{3}{*}{ Species } & \multicolumn{16}{|c|}{ Sample Month } \\
\hline & \multicolumn{4}{|c|}{2005} & \multicolumn{8}{|c|}{2006} & \multirow[t]{2}{*}{ Total } & \multirow[t]{2}{*}{$\%$} & \multicolumn{2}{|c|}{ Subfamily \% } \\
\hline & Sep. & Oct. & Nov. & Dec. & Jan. & Feb. & Mar. & Apr. & May & Jun. & Jul. & Aug. & & & Rainy & Dry \\
\hline Biblidinae & & & & & & & & & & & & & 287 & 30 & & \\
\hline $\begin{array}{l}\text { Biblis hyperia nectanabis (Fruhstorfer, } \\
\text { 1909) }\end{array}$ & 0 & 0 & 0 & 0 & 0 & 0 & 0 & 2 & 1 & 5 & 2 & 2 & 12 & 1.2 & & \\
\hline Callicore s. sorana (Godart, 1824) & 10 & 2 & 0 & 0 & 0 & 1 & 0 & 0 & 8 & 8 & 12 & 7 & 48 & 5 & & \\
\hline $\begin{array}{l}\text { Dynamine p. postverta (Cramer, } \\
\text { 1779) }\end{array}$ & 1 & 0 & 0 & 0 & 0 & 0 & 0 & 1 & 0 & 1 & 1 & 2 & 6 & 0.6 & 19.8 & 57.8 \\
\hline $\begin{array}{l}\text { Eunica tatila bellaria (Fruhstorfer, } \\
\text { 1908) }\end{array}$ & 4 & 7 & 0 & 0 & 0 & 0 & 0 & 0 & 0 & 0 & 0 & 0 & 11 & 1.1 & & \\
\hline Hamadryas f. februa (Hübner, 1823) & 31 & 40 & 19 & 8 & 8 & 16 & 11 & 12 & 22 & 11 & 9 & 16 & 203 & 21.2 & & \\
\hline $\begin{array}{l}\text { Hamadryas f. feronia (Linnaeus, } \\
\text { 1758) }\end{array}$ & 1 & 0 & 0 & 0 & 0 & 0 & 0 & 1 & 1 & 1 & 1 & 2 & 7 & 0.7 & & \\
\hline Charaxinae & & & & & & & & & & & & & 543 & 56.7 & & \\
\hline $\begin{array}{l}\text { Fountainea g. glycerium (Doubleday, } \\
1849 \text { ) }\end{array}$ & 9 & 6 & 0 & 0 & 0 & 0 & 1 & 4 & 212 & 24 & 24 & 26 & 306 & 32 & & \\
\hline $\begin{array}{l}\text { Fountainea halice moretta (H. Druce, } \\
\text { 1877) }\end{array}$ & 13 & 8 & 0 & 0 & 0 & 0 & 0 & 4 & 82 & 28 & 22 & 23 & 180 & 19 & & \\
\hline $\begin{array}{l}\text { Hypna clytemnestra forbesi (Godman } \\
\text { and Salvin, 1884) }\end{array}$ & 8 & 4 & 1 & 0 & 0 & 0 & 1 & 2 & 12 & 7 & 4 & 15 & 54 & 5.6 & 70.2 & 19.9 \\
\hline Prepona l. laertes (Hübner, 1811) & 1 & 0 & 0 & 0 & 0 & 0 & 0 & 0 & 0 & 0 & 0 & 0 & 1 & 0.1 & & \\
\hline Zaretis isidora (Cramer, 1779) & 1 & 0 & 0 & 0 & 0 & 0 & 0 & 0 & 1 & 0 & 0 & 0 & 2 & 0.2 & & \\
\hline Satyrinae & & & & & & & & & & & & & 113 & 11.8 & & \\
\hline Pharneuptychia phares (Godart, 1824) & 3 & 28 & 5 & 0 & 7 & 5 & 0 & 26 & 31 & 3 & 1 & 3 & 112 & 11.7 & 9.3 & 18.8 \\
\hline Taygetis aff. laches (Fabricius, 1793) & 0 & 0 & 0 & 0 & 0 & 0 & 0 & 0 & 0 & 0 & 0 & 1 & 1 & 0.1 & & \\
\hline Morphinae & & & & & & & & & & & & & 13 & 1.4 & 0.6 & 3.5 \\
\hline Opsiphanes i. invirae (Hübner, 1808) & 6 & 3 & 0 & 0 & 0 & 0 & 0 & 1 & 0 & 0 & 1 & 2 & 13 & 1.4 & & \\
\hline Nymphalinae & & & & & & & & & & & & & 1 & 0.1 & 0.1 & 0 \\
\hline Historis a. acheronta (Fabricius, 1775) & 0 & 0 & 0 & 0 & 0 & 0 & 1 & 0 & 0 & 0 & 0 & 0 & 1 & 0.1 & 0.1 & 0 \\
\hline Total & 88 & 98 & 25 & 8 & 15 & 22 & 14 & 53 & 370 & 88 & 77 & 99 & 957 & 100 & 10 & \\
\hline
\end{tabular}

correlation was applied between the abundance of the six most abundant species.

A rarefaction curve was built after 100 randomizations without reposition and plotted together with Chao 1 richness estimator, using EstimateS 8.0 software [33]. Total richness was estimated by extrapolation of the observed species richness in relation to sample effort.

Meteorological data was obtained from the municipality of Buíque, available on ITEP [28].

Butterfly abundance and richness were compared between the sites and between seasons using a two-way ANOVA test. Analyses were performed with the program BioEstat 5.0, [34] adopting a significance level of 0.05 .

Nonmetric multidimensional scaling was used to search for overall differences in species abundance and composition between seasons. Ordination was undertaken for abundance and composition using the Bray-Curtis index. Analysis of similarities (ANOSIM [35]) was used to test differences in species abundance and composition between seasons. The analyses were performed using the software PRIMER 6.0 [36].
To compare this survey with others, we gathered information on different types of Neotropical habitats where fruit bait studies were conducted. Because there was no study of this kind available for the NE Brazil, a general survey of butterflies of an urban Atlantic Rainforest fragment in João Pessoa municipality, Paraíba state [37], was used. All listed fruit-feeding species were considered, and the nomenclature was standardized following Lamas et al. [31].

\section{Results}

3.1. Community Structure. A total of 957 individuals belonging to 15 species of Nymphalidae were trapped. All subfamilies of fruit-feeding butterflies were recorded, with predominance of individuals and species of Charaxinae and Biblidinae. The other subfamilies were represented by only one (Morphinae and Nymphalinae: Coeini) or two species (Satyrinae) (Table 1). The 15 sampled fruit-feeding butterfly species approached the estimated richness for Catimbau National Park (i.e., $19.5 \pm 7.19$ (Figure 2)). 
TABLE 2: Pearson's linear correlation coefficients between each of the six most abundant species, total abundance and richness of fruit-feeding butterflies.

\begin{tabular}{|c|c|c|c|c|c|c|}
\hline & C. sorana & F. glycerium & F. halice moretta & H. februa & H. clytemnestra forbesi & P. phares \\
\hline \multicolumn{7}{|l|}{ C. sorana } \\
\hline F. glycerium & 0.4086 & & & & & \\
\hline F. halice moretta & 0.6134 & $0.9589^{* * *}$ & & & & \\
\hline H. februa & 0.1552 & 0.1480 & 0.1579 & & & \\
\hline H. clytemnestra forbesi & 0.6952 & 0.5852 & 0.7303 & 0.3027 & & \\
\hline P. phares & -0.0877 & 0.5465 & 0.4649 & 0.4974 & 0.2030 & \\
\hline Total abundance & 0.047 & 0.8139 & $0.9474^{* *}$ & 0.2475 & 0.6713 & 0.5457 \\
\hline Richness & $0.771^{*}$ & 0.3096 & 0.5007 & 0.3405 & 0.7779 & 0.1988 \\
\hline
\end{tabular}

Significant values for $P<0.05$ are in bold. Highest positive correlation values: ${ }^{*}$ species versus richness, ${ }^{* *}$ species versus total abundance, ${ }^{* * *}$ between species.

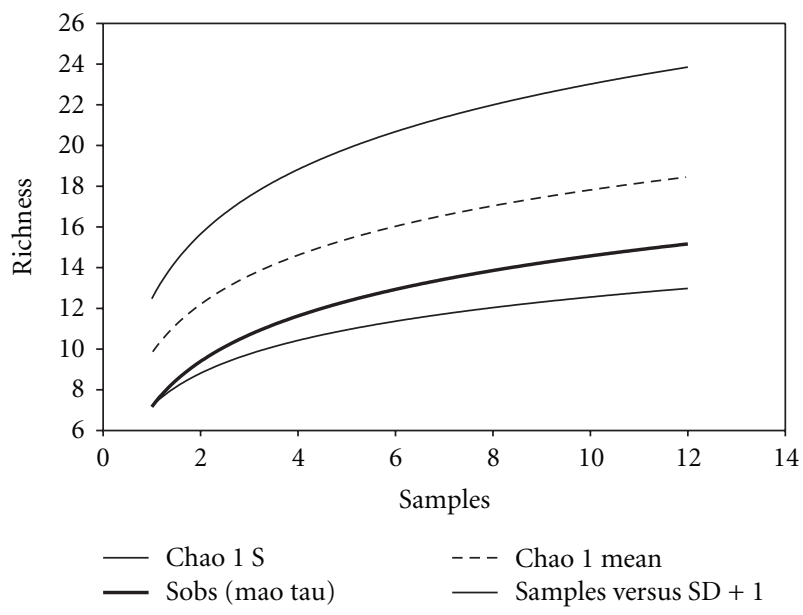

Figure 2: Randomized rarefaction curve (Species observed-Sobs Mao Tay, solid bold line), estimated mean (Chao 1, broken line), and approximate 95\% confidence interval (Chao 1, superior and inferior solid lines) for the fruit-feeding butterfly fauna of the Catimbau National Park.

Fountainea glycerium, F. halice moretta, Hamadryas februa, and Pharneuptychia phares comprised more than $80 \%$ of the overall individuals. Three species were recorded as singletons: Prepona laertes (Hübner, 1811), Historis acheronta (Fabricius, 1775) and Taygetis aff. laches (Fabricius, 1793), and one as a doubleton: Zaretis isidora (Cramer, 1779).

The only species that occurred in all months was $H$. februa, which exhibited low positive correlation (but not significant) with the total abundance and with the other five abundant species (Table 2). The species with the highest positive correlations with other species and with total butterfly abundance was F. halice moretta (Table 2, Figure 3).

Overall, no significant difference was found in abundance $(F=0.58, d f=4.5, P=0.67)$ or species richness $(F=0.35$, $d f=4.5, P=0.84)$ between the sites $(\mathrm{I})-(\mathrm{V})$.

3.2. Seasonality. Both the number of individuals and species peaked in the middle of the rainy season (May/2006) with a progressive and substantial reduction along the dry season (Figure 3). A strong positive correlation was found between monthly abundance and monthly precipitation $\left(r_{s}=0.83\right.$; $P<0.05)$.

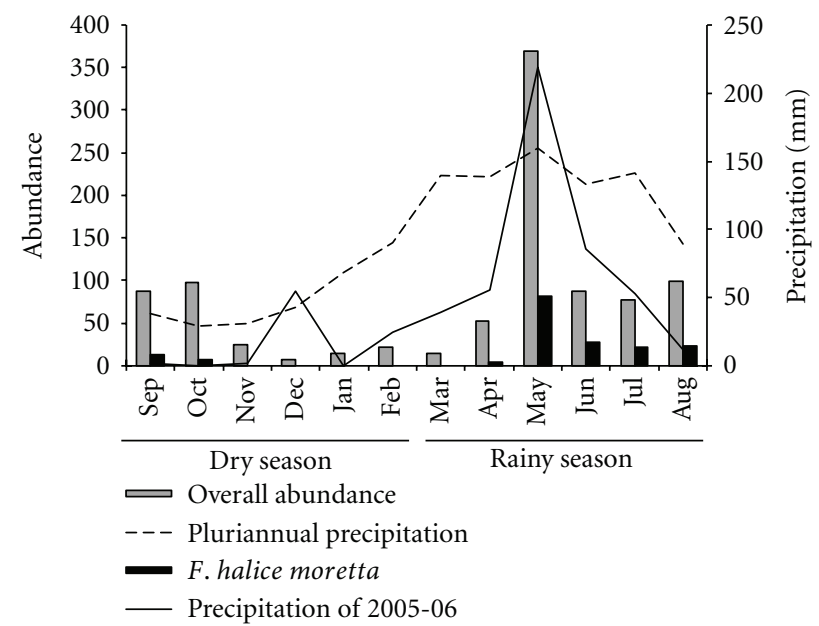

FIGURE 3: Seasonal variation of total fruit-feeding butterfly abundance, Fountainea halice moretta abundance and precipitation, during the sampling period in the Catimbau National Park.

The highest butterfly abundance occurred in May/2006 and the highest richness, in September/2005 (Figure 3). This was the first sampling month, and at the end of it, already $80 \%$ of the species surveyed in the study had already been recorded. Further species were documented only after the beginning of the rainy season in the following year (April/2006). Eunica tatila bellaria (Fruhstorfer, 1908) and Prepona laertes were recorded only in the dry season (September-February), whilst Biblis hyperia (Cramer, 1779), Historis acheronta, and Taygetis aff. laches were only sampled in the rainy season (March-August) (Table 1).

Among the eight species that occurred in both seasons, only $H$. februa showed a significant increase of individuals during the dry season $\left(\chi^{2}=8.28 ; P=0.01\right)$, which was reflected in the predominance of Biblidinae in this period ( $57.8 \%$ of total). Other important seasonal changes occurred in species composition, with increasing populations of Fountainea halice moretta and F. glycerium, leading to a predominance of Charaxinae ( $70 \%$ of total) individuals during the rainy season (Table 1 ).

Both butterfly abundance $(F=7.22$, $d f=1.5$, $P=0.0095)$ and species richness $(F=8.40, d f=1.50$, 


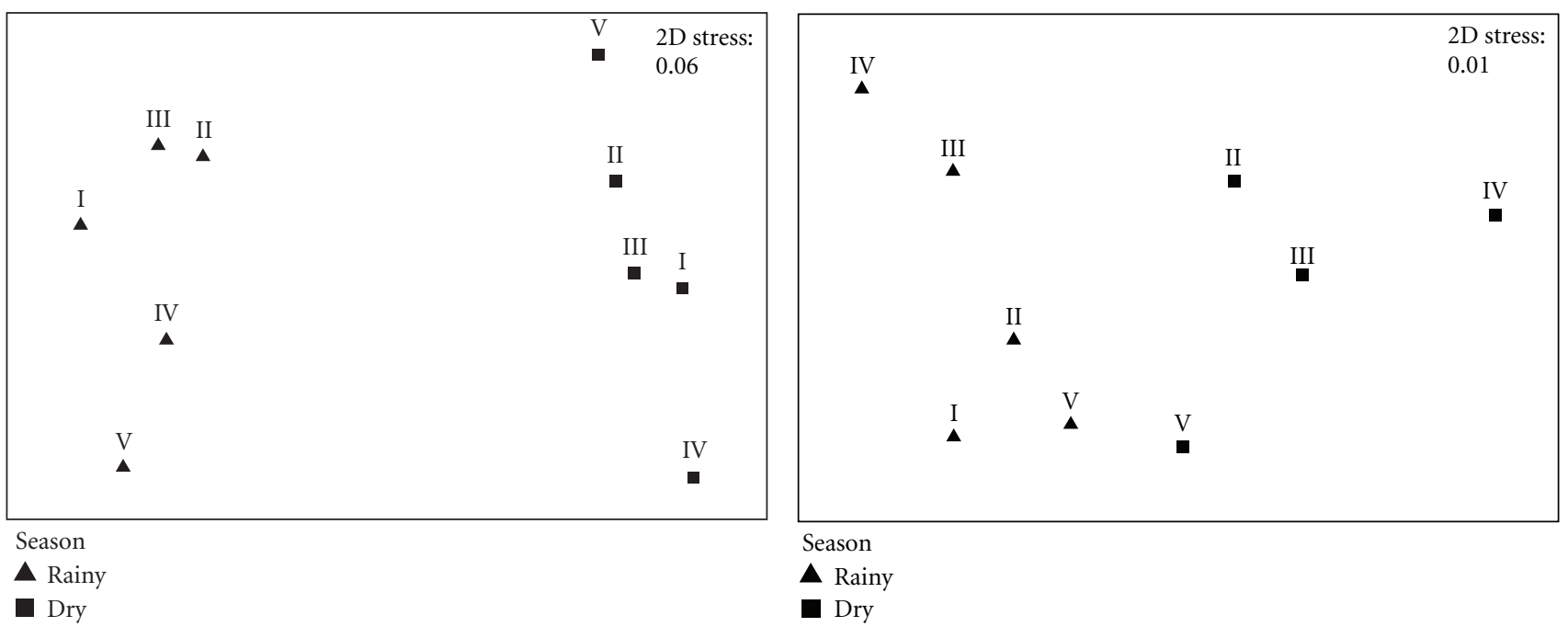

(a) (b)

FIGURE 4: Nonmetric multidimensional scaling (MDS) ordination of the fruit-feeding butterfly community in the rainy and dry seasons, sampled in five sites (I, II, III, IV, V). (a) Species abundance and (b) species composition.

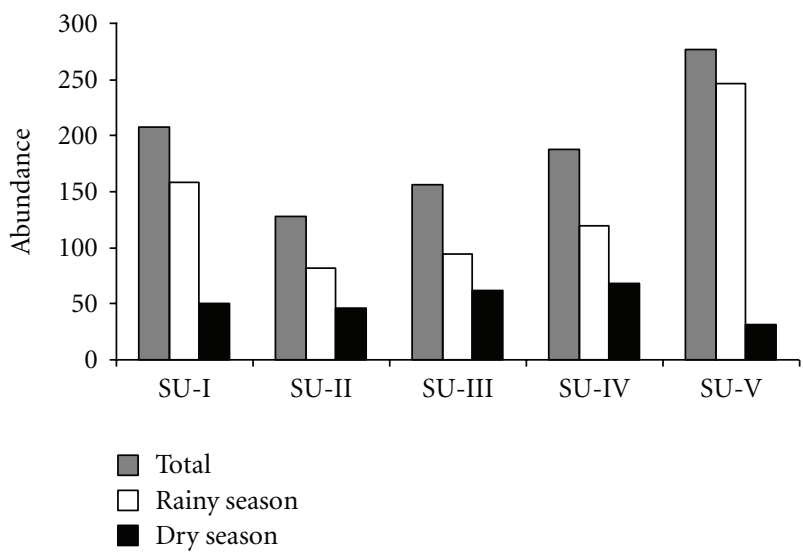

FIGURE 5: Abundance of fruit-feeding butterflies in the rainy/dry seasons and total abundance of the five sample units (SUs) placed in the Catimbau National Park.

$P=0.0057)$ were affected by season, in a manner that the rainy period had significantly more individuals and species. Interaction between these factors was not evident for abundance or species richness.

The distribution pattern of abundance (Figure 4(a), ANOSIM $R=0.964, P=0.8$ ) and of species composition (Figure 4(b), ANOSIM $R=0.676, P=0.8$ ) differed between seasons. There was a major population increase in butterfly abundance of site (V) during the rainy season (Figure 5) and great similarity between seasons in species composition on this site (Figure 4(b)).

\section{Discussion}

4.1. Community Structure. Our results show that the sampling effort was adequate to assess the species richness of fruit-feeding butterflies of the Catimbau National Park. Although well represented on the family level, the local frugivorous butterfly guild is rather poor when compared to other areas of Central and South America (see references in Table 3). Even by adding to our list other three frugivorous species recorded by Nobre et al. [16] during active sampling (Adelpha iphicleola, Dynamine agacles, and Pharneuptychia phares), the total number of species is far from what was found in other seasonally dry tropical forest-Lago Guri, Venezuela (Table 3 ). The vegetation of the Park, characterized by small trees and shrubs, provides a less structurally complex environment than tropical rainforests, which present much more diversified fruit-feeding faunas [2]. Yet, the studied community followed the general tendency found in tropical environments of low individual abundance for most species and also described for other insect groups in the Caatinga, such as bees $[38,39]$ and cerambycid beetles [40].

The local fruit-feeding community is mainly composed by the subfamilies Charaxinae and Biblidinae. Hamadryas $f$. februa (Biblidinae), Fountainea g. glycerium and Fountainea halice moretta (Charaxinae) were dominant throughout the year and very abundant in overall.

The only nymphaline species-Historis acheronta-is probably nonresident, since its larvae feedS on Cecropia, not found in the area (see $[27,31]$ ), and the captured individual was probably migrating.

Satyrinae and Morphinae were also poorly represented. Morphines and large satyrines are typical of forests with extensive canopy cover, which provides shade and diverse microclimatic conditions $[8,42]$. Similarly to what was observed in the Catimbau, the Morphinae were also poorly represented in the Costa Rican deciduous forest [8]. For butterflies, shortage of permanent water bodies influences the absence of many taxa, especially Morphinae and Satyrinae [43]. The thin leaf litter coverage is characteristic of the Caatinga [44] and can also help to explain the low Satyrinae 
TABLE 3: Surveys of fruit-feeding butterflies in Central and South America.

\begin{tabular}{|c|c|c|c|c|c|c|c|}
\hline \multirow{2}{*}{ Area } & \multirow{2}{*}{$\begin{array}{l}\text { Main vegetation } \\
\text { type }\end{array}$} & \multirow{2}{*}{$\begin{array}{l}\text { Sampling } \\
\text { effort }\end{array}$} & \multirow{2}{*}{$\begin{array}{c}\text { Total } \\
\text { species }\end{array}$} & \multirow{2}{*}{ Species/genera } & \multicolumn{2}{|c|}{ Species in common } & \multirow[b]{2}{*}{ Reference } \\
\hline & & & & & absolute value & $\%$ & \\
\hline $\begin{array}{l}\text { Catimbau National Park, } \\
\text { Brazil }\end{array}$ & $\begin{array}{l}\text { Tropical dry forest, } \\
\text { Caatinga }\end{array}$ & $6,000^{*}$ & 15 & 1.15 & - & - & This study \\
\hline Amazon, Brazil & Amazon rainforest & $20,106^{*}$ & 90 & 2.05 & 10 & 66.7 & {$[9]$} \\
\hline Lago Guri, Venezuela & Tropical dry forest & $410^{*}$ & 41 & 1.17 & 9 & 60 & {$[4]$} \\
\hline Brasília, Brazil & $\begin{array}{l}\text { Cerrado/gallery } \\
\text { forest }\end{array}$ & $2,352^{*}$ & 46 & 1.77 & 8 & 53.3 & {$[12]$} \\
\hline João Pessoa, Brazil & Atlantic forest & N/A & 50 & 1.92 & 8 & 53.3 & {$[37]$} \\
\hline Morro Grande, Brazil & Atlantic forest & $36,000^{*}$ & 70 & 1.94 & 6 & 40 & {$[10]$} \\
\hline La Selva Lodge, Ecuador & Floodplain forest & $15,000^{* *}$ & 128 & 3.76 & 4 & 26.7 & {$[5]$} \\
\hline Las Cruces, Costa Rica & $\begin{array}{l}\text { Mid elevation trop- } \\
\text { ical forest }\end{array}$ & $3,024^{*}$ & 43 & 2.69 & 4 & 20 & {$[3]$} \\
\hline $\begin{array}{l}\text { Finca La Selva, Costa } \\
\text { Rica }\end{array}$ & Tropical rainforest & $7,300^{* *}$ & 46 & 1.84 & 3 & 20 & {$[41]$} \\
\hline
\end{tabular}

Sampling effort $=$ approximate number of trap/hours. ${ }^{*}$ understorey traps only, ${ }^{* *}$ understorey and canopy traps. N/A: not applicable (see Section 2.3 ).

richness in the Catimbau. The dry and rotten leaves provide good substrate for camouflage and for fungi development, a diet component of some satyrines [8]. Locally, this niche is almost entirely occupied by the ground dweller, Pharneuptychia phares, which represented almost all of the satyrine records for the Catimbau.

4.2. Seasonality. This study evidenced a highly seasonal pattern of abundance and richness within the local fruitfeeding butterfly community. A significant decline of both variables occurs during the dry season, as a consequence of intense plant defoliation and decreasing fruit availability. It is known that insufficiency of food puts an end to the annual cycle of most butterfly species, some of which migrate to more humid areas, aestivate, or enter reproductive diapauses $[23,38]$. Nonetheless, higher availability of food did not correspond strictly to the rainy period. Thus, in September, the first month of the dry season, the vegetation still exhibited green leaves and abundance of fruits, capable of harboring the richest butterfly fauna of the sampling period. On the other hand, in the first rainy month of this study (March/2006), the food available for both larvae and adults was still scarce.

Seasonality also showed remarkable effects on the butterfly populations when the sample units were analyzed separately. The higher abundance found in the most open and disturbed site $(\mathrm{V})$ reflects the large proportion of common, sun-loving species. However, such predominance vanished during the dry season, when the area became too hot. In this period, the individuals tend to search for cooler areas. On this site, however, species composition did not change significantly between seasons.

At the species level, Hamadryas februa was the only species present in all sampling months, the most abundant species in the dry season, and the second most abundant one in the sampling year. This species is common in another seasonally marked area, the Cerrado [12], and is considered typical of disturbed and fragmented rainforests $[8,9,45]$. The generalist habits and cryptic morphology/behavior were pointed out as determinant factors of the high abundance of this species in the Cerrado [12], and we believe those are very important features influencing its endurance in the Caatinga. Its occurrence throughout the year is very likely due to the capacity of individuals to diapause as non-reproductive adults during the critically dry months. It is intriguing why only this species seems able to do this.

The abundance of Fountainea halice moretta showed the highest correlation with the abundance of other fruitfeeding butterflies and with the overall community. Its monthly abundance finely exemplifies the seasonal fluctuation observed for the whole fruit-feeding community during this study. This subspecies, commonly found in other Caatinga environments (C.E.B. Nobre, unpublished data), is considered to be endemic to the Brazilian semiarid [46] and reveals great potential as a flagship organism for conservation purposes in the region. It is known that interannual instabilities of butterfly populations may occur (see [8]), especially in regions that exhibit accentuated seasonal fluctuations of resources [45], as it is in the Caatinga. It would be of great value to verify if the observed pattern is recurring in other areas.

\section{Acknowledgments}

The authors thank Olaf Mielke and André Freitas for their great help in identifying the butterflies and making possible the access to the collections of UFPR and UNICAMP and bibliographic handouts. They also thank Márcio UeharaPrado and Artur Maia for the reviewing of early versions of the paper and Carolina Liberal for her help in statistical analyses. This research was financially supported by "Fundação O Boticário," the Semi-arid Biodiversity Research Project (PPBIO), and grants from CAPES to C. Nobre and CNPq to C. Schlindwein. 


\section{References}

[1] G. C. Daily and P. R. Ehrlich, "Preservation of biodiversity in small rainforest patches: rapid evaluations using butterfly trapping," Biodiversity and Conservation, vol. 4, no. 1, pp. 3555, 1995.

[2] P. J. DeVries, D. Murray, and R. Lande, "Species diversity in vertical, horizontal, and temporal dimensions of a fruitfeeding butterfly community in an Ecuadorian rainforest," Biological Journal of the Linnean Society, vol. 62, no. 3, pp. 343 364, 1997.

[3] J. B. Hughes, G. C. Daily, and P. R. Ehrlich, "Use of fruit bait traps for monitoring of butterflies (Lepidoptera: Nymphalidae)," Revista de Biologia Tropical, vol. 46, no. 3, pp. 697-704, 1998.

[4] G. Shahabuddin and J. W. Terborgh, "Frugivorous butterflies in Venezuelan forest fragments: abundance, diversity and the effects of isolation," Journal of Tropical Ecology, vol. 15, no. 6, pp. 703-722, 1999.

[5] P. J. Devries and T. R. Walla, "Species diversity and community structure in neotropical fruit-feeding butterflies," Biological Journal of the Linnean Society, vol. 74, no. 1, pp. 1-15, 2001.

[6] K. S. Bobo, M. Waltert, H. Fermon, J. Njokagbor, and M. Mühlenberg, "From forest to farmland: butterfly diversity and habitat associations along a gradient of forest conversion in Southwestern Cameroon," Journal of Insect Conservation, vol. 10, no. 1, pp. 29-42, 2006.

[7] M. Uehara-Prado, K. S. Brown, and A. V. L. Freitas, "Species richness, composition and abundance of fruit-feeding butterflies in the Brazilian Atlantic Forest: comparison between a fragmented and a continuous landscape," Global Ecology and Biogeography, vol. 16, no. 1, pp. 43-54, 2007.

[8] P. J. DeVries, "Papilionidae, Pieridae and Nymphalidae," in The Butterflies of Costa Rica and their Natural History, vol. 1, p. 327, Princeton University Press, NJ, USA, 1987.

[9] F. A. Ramos, "Nymphalid butterfly communities in an Amazonian forest fragment," Journal of Research on the Lepidoptera, vol. 35, pp. 29-41, 2000.

[10] M. Uehara-Prado, K. S. Brown, and A. V. L. Freitas, "Biological traits of frugivorous butterflies in a fragmented and a continuous landscape in the south Brazilian Atlantic Forest," Journal of the Lepidopterists' Society, vol. 59, no. 2, pp. 96-106, 2005.

[11] J. Barlow, W. L. Overal, I. S. Araujo, T. A. Gardner, and C. A. Peres, "The value of primary, secondary and plantation forests for fruit-feeding butterflies in the Brazilian Amazon," Journal of Applied Ecology, vol. 44, no. 5, pp. 1001-1012, 2007.

[12] C. E. G. Pinheiro and J. V. C. Ortiz, "Communities of fruitfeeding butterflies along a vegetation gradient in central Brazil," Journal of Biogeography, vol. 19, no. 5, pp. 505-511, 1992.

[13] L. Fortunato L and A. Ruszczyk, "Comunidades de lepidópteros frugívoros em áreas verdes urbanas e extraurbanas de Uberlândia, MG," Revista Brasileira de Biologia, vol. 57, no. 1, pp. 79-87, 1997.

[14] M. A. B. Gusmão and A. J. Creão-Duarte, "Diversidade e análise faunística de Sphingidae (Lepidoptera) em área de brejo e Caatinga no Estado da Paraíba, Brasil," Revista Brasileira de Zoologia, vol. 21, no. 3, pp. 491-498, 2004.

[15] J. A. Duarte and C. Schlindwein, "The highly seasonal Hawkmoth fauna (Lepidoptera: Sphingidae) of the Caatinga of northeast Brazil: a case study in the state of Rio Grande do Norte," Journal of the Lepidopterists' Society, vol. 59, no. 4, pp. 212-218, 2005.
[16] C. E. B. Nobre, C. Schlindwein, and O. H. Mielke, "The butterflies (Lepidoptera: Papilionoidea and Hesperioidea) of the Catimbau National Park, Pernambuco, Brazil," Zootaxa, no. 1751, pp. 35-45, 2008.

[17] E. H. Bucher, "Chaco and Caatinga-South American arid savannas, woodlands and thickets," in Ecology of Tropical Savannas, B. J. Huntey and B. H. Walther, Eds., pp. 48-79, Springer, New York, NY, USA, 1982.

[18] D. Andrade-Lima, “The Caatinga's dominion," Revista Brasileira de Botânica, vol. 4, pp. 149-155, 1981.

[19] D. Prado, "As caatingas da América do Sul," in Ecologia e Conservação da Caatinga, I. R. Leal, M. Tabarelli, and J. M. C. Silva, Eds., pp. 3-73, Editora Universitária da UFPE, Recife, Brasil, 2003.

[20] C. M. H. Castelletti, J. M. C. Silva, M. Tabarelli, and A. M. M. Santos, "Quanto ainda resta da Caatinga? Uma estimativa preliminar," in Ecologia e Conservação da Caatinga, I. R. Leal, M. Tabarelli, and J. M. C. Silva, Eds., pp. 91-100, Editora Universitária da UFPE, Recife, Brasil, 2004.

[21] I. R. Leal, J. M. C. Da Silva, M. Tabarelli, and T. E. Lacher, "Changing the course of biodiversity conservation in the caatinga of northeastern Brazil," Conservation Biology, vol. 19, no. 3, pp. 701-706, 2005.

[22] P. K. Endress, Diversity and Evolutionary Biology of Tropical Flowers, Cambridge, UK, 1996.

[23] D. H. Janzen, "Insects," in Costa Rican Natutal History, D. H. Janzen, Ed., pp. 623-623, The University of Chicago Press, Chicago, Ill, USA, 1983.

[24] P. J. DeVries, "Checklist of butterflies and natural history," in Costa Rican Natural History, D. H. Janzen, Ed., pp. 654-678, University of Chicago Press, Chicago, Ill, USA, 1983.

[25] P. C. Motta, "Butterflies from the Uberlândia region, Central Brazil: species list and biological comments," Brazilian Journal of Biology, vol. 62, no. 1, pp. 151-163, 2002.

[26] F. Pinheiro, I. R. Diniz, D. Coelho, and M. P. S. Bandeira, "Seasonal pattern of insect abundance in the Brazilian cerrado," Austral Ecology, vol. 27, no. 2, pp. 132-136, 2002.

[27] K. V. S. A. Andrade, M. J. N. Rodal, M. F. A. Lucena, and A. P. S. Gomes, "Composição florística de um trecho do Parque Nacional do Catimbau, Buíque, Pernambuco-Brasil," Hoehnea, vol. 31, pp. 75-281, 2004.

[28] ITEP-Instituto de Tecnologia de Pernambuco (Technology Institute of Pernambuco), 2009.

[29] J. M. C. Silva, M. Tabarelli, M. T. Fonseca, and L. Lins, Biodiversidade da Caatinga: Áreas e Ações Prioritárias para a Conservação, Ministério do Meio Ambiente, Brasília, Brazil, 2004.

[30] A. P. S. Gomes, M. J. N. Rodal, and A. L. Melo, "Florística e fitogeografia da vegetação arbustiva subcaducifólia da chapada de São José, Buíque, Pernambuco-Brasil," Acta Botanica Brasileira, vol. 20, no. 1, pp. 1-12, 2006.

[31] G. Lamas, M. M. Casagrande, A. L. Viloria, and T. W. Pyrcz, "Nymphalidae," in Atlas of Neotropical Lepidoptera, Checklist: Part 4A, Hesperioidea-Papilionoidea, G. Lamas, Ed., pp. 171274, Association for Tropical Lepidoptera, Gainesville, Fla, USA, 2004.

[32] Statsoft Inc., "Statistica 6.0,” Statsoft, Tulsa, Okla, USA, 2002.

[33] R. K. Cowell and S. Estimate, "Statistical estimation of species richness and shared species from samples," version 8, 2006, http://purl.oclc.org/estimates.

[34] M. Ayres, M. AyresJr, D. L. Ayres, and A. A. Santos, "BIOESTAT-aplicações estatísticas nas áreas das ciências biomédicas,” Ong Mamiraua, Belém, Brazil, 2007. 
[35] K. R. Clarke, "Non-parametric multivariate analyses of changes in community structure," Australian Journal of Ecology, vol. 18, no. 1, pp. 117-143, 1993.

[36] K. R. Clarke and R. N. Gorley, Primer v6: User Manual/Tutorial, Plymouth Marine Laboratory, Plymouth, UK, 2006.

[37] J. Kesselring and H. Ebert, "Relação das borboletas encontradas na mata do buraquinho, João Pessoa, estado da Paraíba, Brasil," Revista Nordestina de Biologia, vol. 2, no. 1/2, pp. 105118, 1982.

[38] C. F. Martins, "Comunidade de abelhas (Hym., Apoidea) da Caatinga e do Cerrado com elementos de campo rupestre do estado da Bahia, Brasil," Revista Nordestina de Biologia, vol. 9, pp. 225-257, 1994.

[39] C. M. L. Aguiar and C. F. Martins, "Abundância Relativa, Diversidade e Fenologia de Abelhas (Hymenoptera, Apoidea) na Caatinga, São João do Cariri, Paraíba, Brasil," Iheringia, vol. 83, pp. 151-163, 1997.

[40] A. C. D. Maia, L. Iannuzzi, C. E. B. Nobre, and C. M. R. Albuquerque, "Padrões Locais de Diversidade de Cerambycidae (Insecta, Coleoptera) em Vegetação de Caatinga," in Ecologia e Conservação da Caatinga, I. R. Leal, M. Tabarelli, and J. M. C. Silva, Eds., pp. 391-433, Editora Universitária da UFPE, Recife, Brasil, 2003.

[41] P. J. DeVries, "Stratification of fruit-feeding nymphalid butterflies in a Costa Rican rainforest," Journal of Research on the Lepidoptera, vol. 26, pp. 98-108, 1988.

[42] A. M. Young, "Studies on comparative ecology and ethology in adult populations of several species of Morpho butterflies (Lepidoptera: Morphidae)," Studies on the Neotropical Fauna and Environment, vol. 8, pp. 17-50, 1973.

[43] K. S. Brown and A. V. L. Freitas, "Butterfly communities of urban forest fragments in Campinas, São Paulo, Brazil: structure, instability, environmental correlates, and conservation," Journal of Insect Conservation, vol. 6, no. 4, pp. 217-231, 2002.

[44] I. R. Leal, "Diversidade de formigas em diferentes unidades de paisagem da Caatinga," in Ecologia e Conservação da Caatinga, I. R. Leal, M. Tabarelli, and J. M. C. Silva, Eds., pp. 435-461, Editora Universitária da UFPE, Recife, Brasil, 2003.

[45] K. S. Brown Jr., "Borboletas da Serra do Japi: diversidade, Habitats, recursos alimentares e variação temporal," in História Natural da Serra do Japi: Ecologia e Preservação de uma Área Florestada no Sudeste do Brasil, L. P. C. Morellato, Ed., pp. 142-186, UNICAMP, Campinas, Brazil, 1992.

[46] A. Soares, C. E. A. Júlio, C. A. Caetano, N. Tangerini, A. C. Faria, and J. E. Costa, "Lista da lepidopterofauna diurna da região da calha do rio São Francisco, estado de Minas Gerais, municípios de Itacarambi, Jaíba, Manga e Matias Cardoso," Boletim do Museu Nacional, vol. 402, pp. 1-11, 1999. 

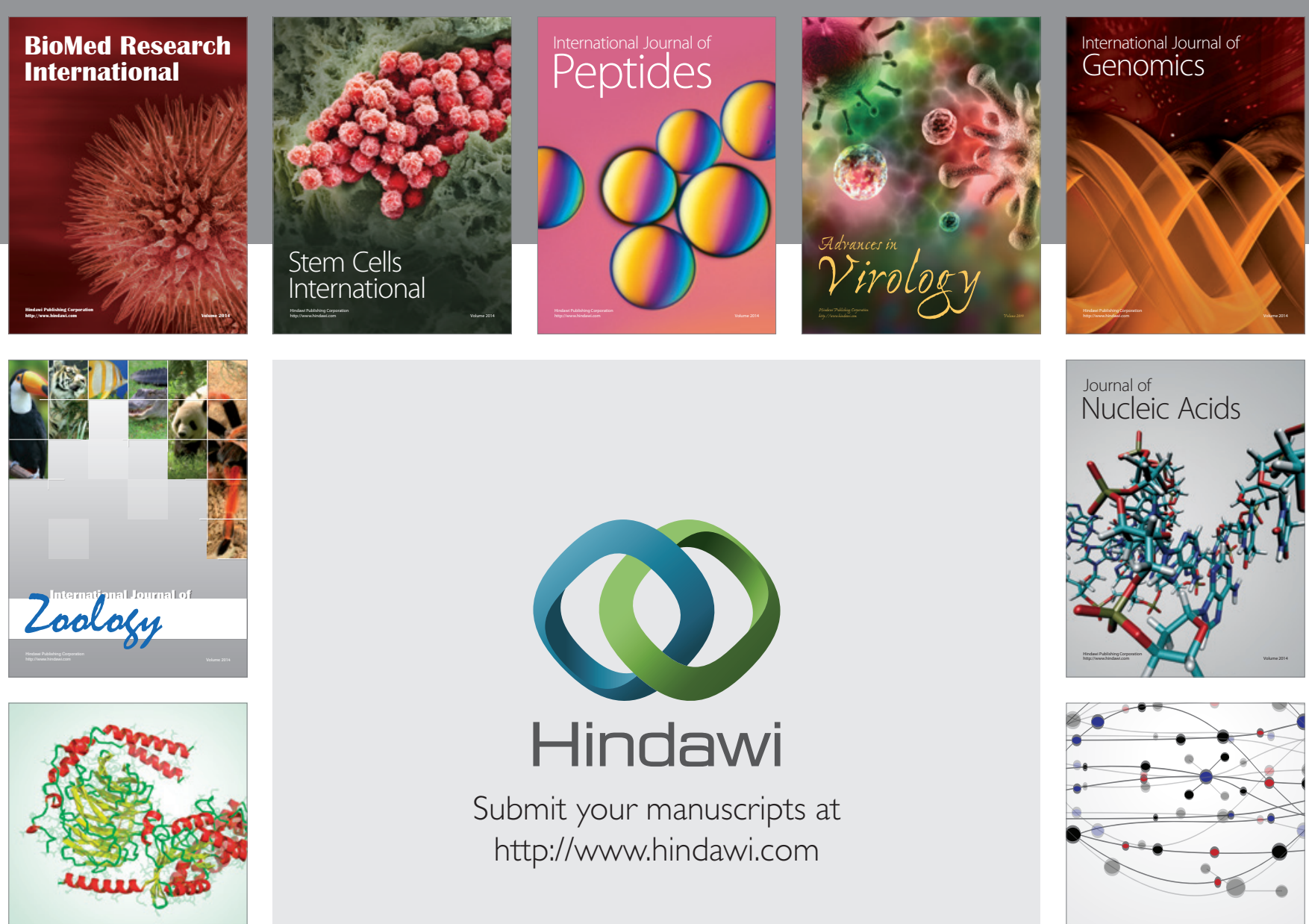

Submit your manuscripts at

http://www.hindawi.com

Signal ${ }^{\text {Jumal }}$ Transduction
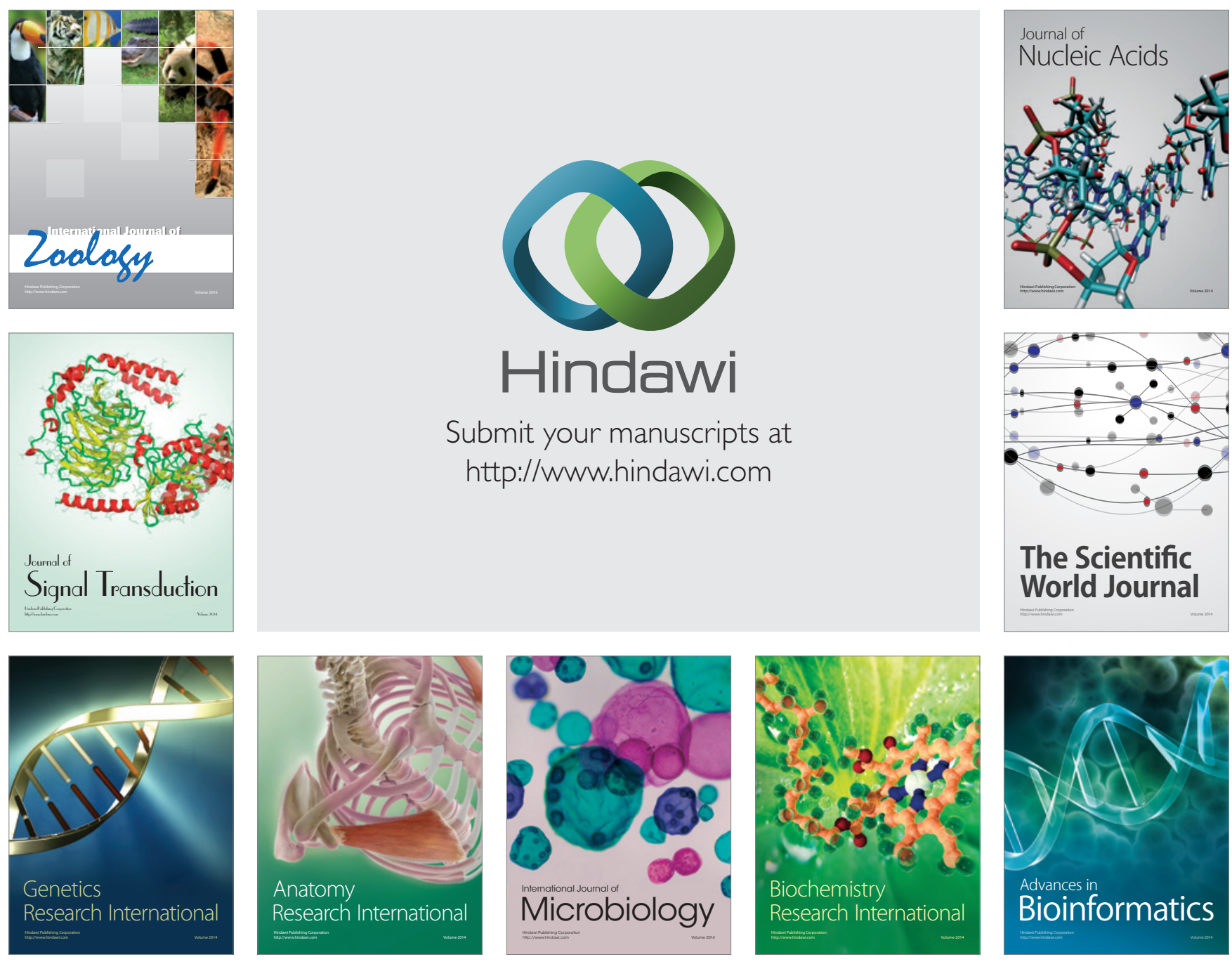

The Scientific World Journal
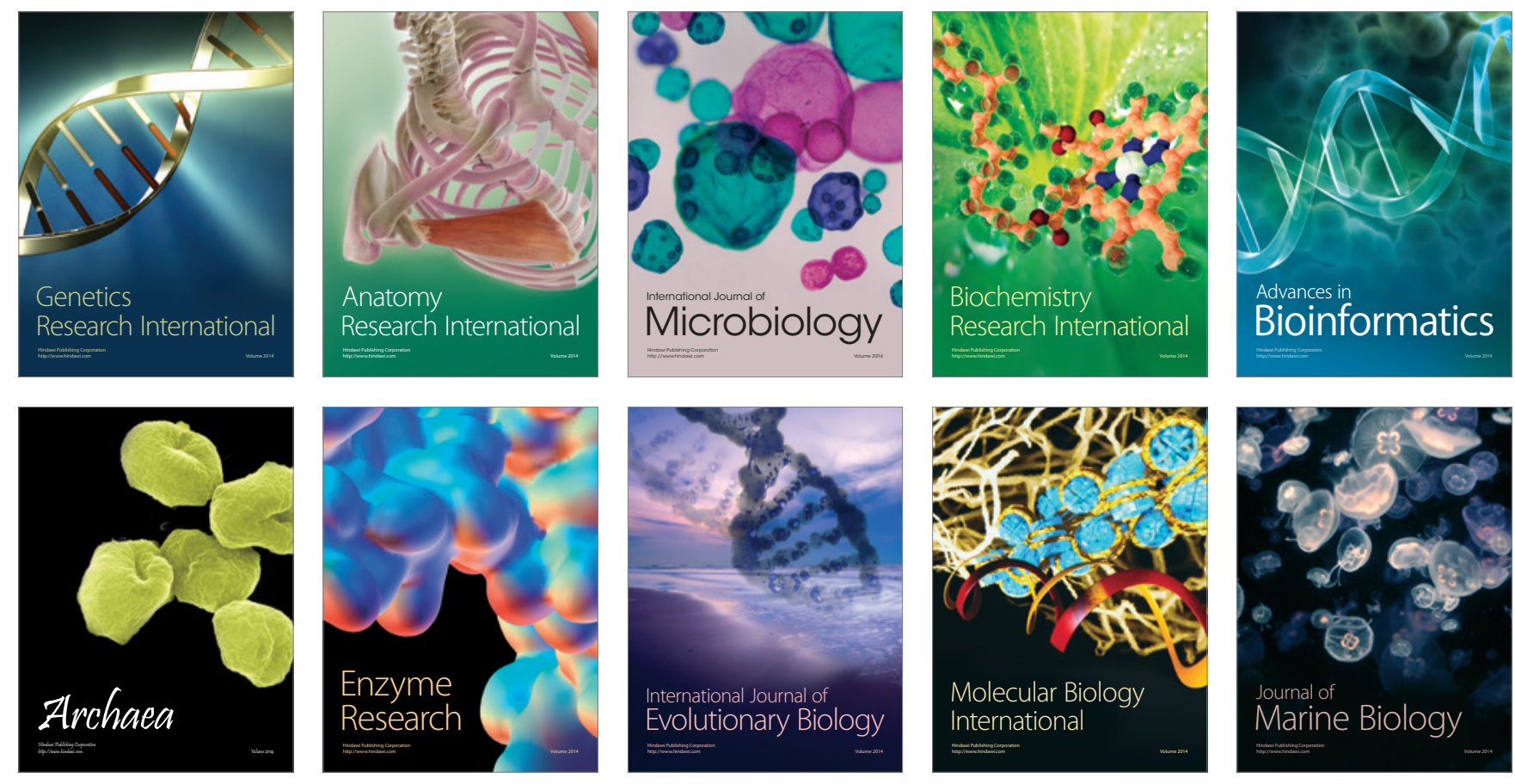